\title{
Ethnologies
}

\section{The Mountie: From Dime Novel to Disney. By Michael Dawson. (Toronto: Between the Lines, 1998. ISBN 1-896357-16-4, pbl.)}

\section{Kristin Harris}

Volume 24, numéro 2, 2002

Musées

Museums

URI : https://id.erudit.org/iderudit/006653ar

DOI : https://doi.org/10.7202/006653ar

Aller au sommaire du numéro

\section{Éditeur(s)}

Association Canadienne d'Ethnologie et de Folklore

ISSN

1481-5974 (imprimé)

1708-0401 (numérique)

Découvrir la revue

Citer ce compte rendu

Harris, K. (2002). Compte rendu de [The Mountie: From Dime Novel to

Disney. By Michael Dawson. (Toronto: Between the Lines, 1998. ISBN

1-896357-16-4, pbk.)]. Ethnologies, 24(2), 256-259.

https://doi.org/10.7202/006653ar

Ce document est protégé par la loi sur le droit d'auteur. L'utilisation des services d'Érudit (y compris la reproduction) est assujettie à sa politique d'utilisation que vous pouvez consulter en ligne.

https://apropos.erudit.org/fr/usagers/politique-dutilisation/
Cet article est diffusé et préservé par Érudit.

Érudit est un consortium interuniversitaire sans but lucratif composé de l'Université de Montréal, l'Université Laval et l'Université du Québec à Montréal. Il a pour mission la promotion et la valorisation de la recherche. https://www.erudit.org/fr/ 
careful to critically examine his sources and to present any potential limitations.

While this book focuses on trends and patterns in the development of domestic architecture over a three-century period, Ward is careful to point out the exceptions. He cautions the reader to remember that this development occurred at different paces for different economic levels. One point I would like to note, however, is that while Peter Ward does touch on the impact of gender on domestic architecture, I think that this aspect could have been more thoroughly developed. He ends his book with a paragraph on the influence of individuality and the uniqueness of the self on the development of domestic architecture, an important point. While domestic architecture developed in trends, the strength of the individual has had a high degree of impact.

This book is a well-written, engaging introduction to the history of domestic space and its impact on privacy in the home and in the community. Peter Ward has done an adequate job of demonstrating the way in which family and social relationships have transformed Canadian domestic architecture and increased the levels of both personal and family privacy.

Michele L. Gillingham

Memorial University of Newfoundland

The Mountie: From Dime Novel to Disney. By Michael Dawson. (Toronto: Between the Lines, 1998. ISBN 1-896357-16-4, pbk.)

Standing alongside other such icons as the beaver and the maple leaf, the Mountie has actually been both revered and reviled throughout the history of Canada. In his first book, Dawson tackles this most ubiquitous of Canadian symbols. While today we may view the Mountie as a somewhat bland, mildly heroic, brightly uniformed member of a largely ceremonial police force, almost a Canadian version of the Beefeater, this was not always the case. In this insightful and revealing text, Dawson depicts the changing face of the Mountie to both Canadians and those outside our borders.

Dawson takes a historical approach to his subject matter, leading the reader through various pivotal moments in both Canadian and RCMP history. While this initially appears to be his sole theoretical 
frame, it becomes evident that Dawson draws upon a number of themes that recur throughout the book, complementing the chronology that he has created. Attention to the anti-modern (McKay) and imagined communities (Anderson) theoretically fills in the gaps and provides a more satisfying approach to the myth of the Mountie.

The book is divided into seven chapters, the middle five focusing on chronologically divided themes. In these core chapters Dawson deals with more than just defining moments in RCMP history. He examines the role of the Mountie in novel, film, consumerism, nationalism, modernity, and postmodernity. Additionally, the image(s) of and myth(s) surrounding the Mountie are continually examined and reexamined through the eyes of each time frame presented. One recurring premise throughout the book is the concern of the RCMP, as an organization, as to how their members are portrayed to the public at large. Thus, Dawson delineates the various myths surrounding the RCMP, and how they were used to create an archetype of the quintessential Mountie. For example, his summary of the history of the RCMP, as it was conventionally accepted in the first half of the twentieth century, emphasizes the role of the original 1873 North-West Mounted Police as Sir John A. Macdonald's harbinger of "Peace, Order and Good Government" as outlined in the British North American Act. They quelled Indian unrest in the North West Territories with their "March West," overcoming tremendous hardship and chasing out American whiskey traders. After peace was restored, the small force continued to police western Canada, seeing through crises related to Indian treaties, the building of the Canadian Pacific Railway, the Yukon Gold Rush and the Winnipeg Strike (6-10). In the older Mountie narrative, RCMP officers were contrasted with the "other": Indian, francophone, immigrant. Dawson challenges this history, not only providing evidence to dispute this particular narrative, but to show how Mountie history has been revised. Perhaps the most pivotal point of alteration was during a climax of nationalistic sentiment, the 1973 Centennial celebrations. As Dawson states, the revisionist story of the RCMP, "in its avoidance of jarring ethnic generalities, [was] a more tolerant and inclusive narrative than the classic version" (113). The new Mountie, liberal and striving for the better good of community and country, provided a gentler image than the old-school Mountie, portrayed as lone and individualistic. The less flattering characteristics of RCMP history imperialism, sexism, racism - were removed (180). The new story emphasized continuity, inclusion and progress. 
Dawson's comment that, "national heroes are made, not born," follows throughout the text (31). He deals with the myth of the Mountie as it has been presented to the Canadian and international public. Earlier images could be found in fiction and films in which, Dawson argues, the Mountie predominated as both an anti-modern hero, and as a representation of Canada as an imagined community. Furthermore, he was an amalgam of a number of abstract qualities: he was honourable, well-meaning, used common sense, and maintained the status quo. As such, the Mountie became a sought-after commodity not only for page and screen writers, but for marketers of all kinds of commercial products, particularly during the time of the RCMP's centenary. Dawson illustrates the inconsistency of the RCMP as an organization in terms of approval and rejection of particular products, dependent on the specific image they wished to portray at the time. Packets of sugar were accepted. Potato chips and aluminum cans were rejected, for fear that Mountie images would be strewn as litter (141). Most products emblazoned with the image of the Mountie have created little or no reaction from the Canadian public at large. In recent memory, however, one consumerist link has aroused the ire of many Canadians. That, of course, is when the RCMP sold the image of the Mountie to Disney. However, the RCMP defended this move as protection against increasing low-quality, tacky portrayals of the Mountie, not just in souvenirs, but in professional wrestling and pornography videos as well. Dawson argues that the new marketing approach removes the image from the reality of the force, taming the Mountie through calendars and teddy bears (173). As such, the complicated history of the RCMP is detached from the famous red coat that adorns said marketed objects.

Dawson opens his concluding chapter with a narrative about two American tourists who, in 1956, wrote to the New Brunswick travel authorities, complaining that after "driving 30,000 miles in your lovely country," they only saw one Mountie dressed, "as you show them in the books" (176). This is truly the prevailing image of the RCMP, and indeed, of Canada, to the outside world. From the Mountie movies of the 1930s, to the television program "Due South" in the 1990s, images of the Mountie in material and popular culture have indeed likened Anglophone Canada as an imagined community.

While the final chapter sums up Dawson's main arguments, it merely hints at how the past of the RCMP may inform the future of the Mountie image. Perhaps it is the linear approach of the rest of the book that 
underlies this final chapter, illustrated in Dawson's words, "histories... are central to the understanding of national identity and contemporary Canadian debates" (185). While it would perhaps have been more satisfying to abandon a historical summary at the end of the text, Dawson's book does leave the reader with food for thought, namely about symbol and community and representation of nation and nationhood.

Kristin Harris

Memorial University of Newfoundland

The Second Greatest Disappointment: Honeymooning and Tourism at Niagara Falls. By Karen Dubinsky. (Toronto: Between the Lines, 1999. 290 p., illus., \$29.95. ISBN 1-896357-23-7)

In the Introduction to The Second Greatest Disappointment, Karen Dubinsky confides to the reader that her inspiration for the book is both her "own adult curiosity about the culture in which my parents came of age" (2) and her discovery of Niagara Falls, Ontario as "the greatest theme park of heterosexuality I had ever witnessed" (3). The author states that her work is basically a history of tourism at Niagara Falls, but it is more than that. By framing tourism's development through the honeymoon, Dubinsky sheds light upon the forces that helped shape and develop Niagara Falls into a North American cultural icon.

The scope of the book is ambitious and the author's approach justifiably interdisciplinary. Using source materials that span two centuries, Dubinsky argues that the association of the honeymoon with Niagara Falls evolved over time along with people's attitudes towards sexuality, particularly heterosexuality.

While its reputation as the "honeymoon capital of the world" crystallized after the Second World War, the process began with the wedding tours of the $19^{\text {th }}$ century when the town of Niagara Falls was a popular summer resort among the monied classes.

From this early period of development comes the story of a business rivalry that became so bitter a Royal Commissioner, Edmund Burke Wood, was appointed to investigate visitors' complaints. Researchers who are interested in the conflicts that arise over space when its meaning is imposed from without will find this account worthy of note. The 